\title{
Individual Attitudes Toward Corruption: Do Social Effects Matter?*
}

\author{
Roberta Gatti \\ Development Research Group \\ The World Bank \\ Stefano Paternostro \\ Poverty Reduction Group \\ The World Bank \\ Jamele Rigolini \\ Economics Department \\ New York University
}

\begin{abstract}
Using individual-level data for 35 countries, we investigate the microeconomic determinants of attitudes towards corruption. We consistently find women, employed, less wealthy, and older individuals to be more averse to corruption. We also provide evidence that social effects play an important role in determining individual attitudes towards corruption, as these are robustly and significantly associated with the average level of tolerance of corruption in the region. This finding lends empirical support to theoretical models where corruption emerges in multiple equilibria and suggests that "big-push" policies might be particularly effective in combating corruption.
\end{abstract}

World Bank Policy Research Working Paper 3122, August 2003

The Policy Research Working Paper Series disseminates the findings of work in progress to encourage the exchange of ideas about development issues. An objective of the series is to get the findings out quickly, even if the presentations are less than fully polished. The papers carry the names of the authors and should be cited accordingly. The findings, interpretations, and conclusions expressed in this paper are entirely those of the authors. They do not necessarily represent the view of the World Bank, its Executive Directors, or the countries they represent. Policy Research Working Papers are available online at http://econ.worldbank.org.

*We thank Giorgio Topa, Aart Kraay, and Steve Knack for useful comments and discussions. 


\section{Introduction}

Curbing corruption has long been recognized as crucial to the success of policy actions. An extensive body of literature has by now documented the adverse effect of corruption on growth and investment (Mauro, 1995 and Kaufman et al., 1999), on the allocation of public spending on education and health (Mauro, 1997), and, more generally, on the efficient allocation of resources (Krueger, 1974). In parallel, a growing literature has studied the determinants of corruption in an attempt to identify effective policy instruments to combat it. For instance, corruption has been found to be lower in countries with a higher degree of female participation to public life (Dollar et al., 2001, and Swamy et al., 1999); with a higher freedom of press (Treisman, 2000); with a higher degree of competition (Ades and di Tella, 1999); or with more variable inflation (Braun and di Tella, 2002). With the sole exception of Swamy et al. (2001), all of these studies have relied exclusively on cross-country data. However, in the context of the analysis of corruption, crosssectional analyses at the country level can be in principle problematic, as they do not disentangle the effect of the variables of interest from country-specific institutional factors that are not easily captured by proxies. Furthermore, an in-depth analysis of the microeconomic determinants of corruption can provide more detailed guidance for the targeting of anti-corruption policies.

In this paper we systemically investigate the determinants of corruption at the individual level using data from the World Values Survey (henceforth: WVS), a cross-country program coordinated by the Institute for Social Research of the University of Michigan. The WVS is a questionnaire on individual values and personal characteristics conducted in more than fifty countries, and, among others, contains information on individual's attitudes towards corruption (see below, section IV, for more details).

Our work contributes to the existing literature in two distinct ways. First, it enriches the understanding of corruption with a detailed analysis of its determinants at the individual level across a large number of developed and developing countries. We find women, employed, less wealthy, and older individuals to be more averse to corruption. These results are robust to a number of alternative specifications, including those that account for coun- 
try and regional fixed effects. Second, it provides evidence that the social environment has a strong influence on the individual attitudes towards corruption. We find that, ceteris paribus, individuals living in regions where people are on average relatively less averse to corruption tend as well to be more forgiving of corruption. This evidence confirms the predictions of theoretical models that highlight the importance of social effects. For example, in Andvig and Moene (1990), the individual incentive to be corrupt is higher the more corruption is widespread, because it is easier to both find corruptible officials as well as to escape punishment. In the same vein, Tirole (1996) shows that, because of information asymmetries, individuals from a group with a bad reputation have less of an incentive to behave honestly.

To our knowledge, our results are the first to systematically document the presence of social effects in corruption. As it has been argued in the case of development traps (Rosenstein-Rodan, 1943, Murphy et al., 1989, Paternostro, 1997), the presence of social effects implies that at the individual level incentives to fight corruption can be low. Therefore, from a policy point of view, social effects imply that an effective fight against corruption often needs to be a coordinated "big push" operating on several fronts at once (Collier, 1999). ${ }^{1}$

The paper is organized as follows. Section II reviews the existing literature. Section III discusses the empirical specification and related econometric issues. Section IV describes the data. Section V presents the results, and Section VI concludes.

\section{Existing literature}

Two independent strains of literature provide a framework for our work: studies on determinants of corruption and studies of the effects of social networks. Furthermore, there also exists a growing literature that uses the WVS to investigate socio-economic phenomena. We review all three of them below.

\footnotetext{
${ }^{1}$ To be sure, there exist in theory cases where a single, well-targeted policy can act as a "social-multiplier" and drive the economy out of a bad equilibrium. Nevertheless, given the persistence and extent of corruption, and the many unsuccessful spurious attempts to fight it, this does not seem to be the case in practice.
} 


\section{II.1 Theory and Empirics of Corruption}

Since the seminal contributions of Becker and Stigler (1974) and Rose-Ackerman (1978), corruption has often been studied in a principal-agent framework where the government (the principal) tries to motivate its government official (the agent) to be honest. Although some researchers have argued that a minimal amount of corruption might be efficient because it removes government imposed rigidities (Leff, 1964, Huntington, 1968), or allocates scarce resources to those with the highest willingness to pay (Beck and Maher, 1986, Lien, 1986), the leading view is that, overall, corruption has adverse effects on growth and economic efficiency. Under a corrupt regime, rent-seeking creates obvious distortions (Krueger, 1974). Moreover, agents may also have higher incentives to allocate productive resources to rent-seeking rather than production activities (Baumol, 1990, Murphy, Shleifer and Vishny, 1991), and government official may increase endogenously the amount of red tape in order to extract more rents (Banerjee, 1997). ${ }^{2}$ Empirical studies tend to confirm this view. Mauro $(1995,1998)$ finds that higher levels of corruption are associated with lower growth rates and that more corrupted governments tend to spend more in sectors where it is easier to practice rent-seeking activities. In parallel, Knack and Keefer (1997) find that economic growth is higher in countries where people trust each other and respect civic norms.

In a related strand of research, several studies have investigated how corruption can be the result of a bad equilibrium. Andvig and Moene (1990) argue that the higher the frequency of bureaucratic corruption, the higher is the propensity for a bureaucrat to be corrupted; hence, multiple equilibria with various levels of corruption may arise. In their model, the equilibrium corruption level depends on both supply and demand effects. Demand effects arise because the higher the proportion of corrupted government officials, the easier it is for an agent to find a corruptible official. On the supply side, they introduce an exogenous probability of getting caught by another official, but if the supervisor is also corrupted the official can bribe the latter in order to keep her job. Hence, the higher the number of corrupted officials, the stronger are the incentives for an official to

\footnotetext{
${ }^{2}$ For more detailed reviews of those issues, see Bardhan (1997) and Tanzi (1998).
} 
be corrupted. ${ }^{3}$ Tirole (1996) analyzes the effects of group reputation on the individual's incentives to be corrupted. He shows that, if the behavior of an individual can only be imperfectly observed and the individual's reputation depends in part on the reputation of the group the individual belongs to, agents from groups that had a bad reputation in the past may have strong incentives to continue behaving badly. This branch of the literature suggests that social effects can have a strong effect on individual behavior.

Finally, an increasing number of studies have investigated empirically the determinants of corruption. For example, Ades and di Tella (1999) find that higher degrees of competition are associated with lower levels of corruption; Treisman (2000) establishes the association of corruption with religion, colonial origins, and the freedom of press; Fisman and Gatti (2002) find corruption to be lower in countries with higher fiscal decentralization. However, all of these studies rely on cross-country and mostly cross-sectional data on corruption and, as a result, cannot analyze the extent to which personal characteristics consistently influence individual's attitudes towards corruption. With the exception of Swamy et al. (2001), who find that women tend to be significantly less corrupted, we are not aware of empirical studies that analyze the determinants of corruption at the individual level, or that investigate the relevance of social effects.

\section{II.2 Empirical Literature on Social Networks}

There is a substantial literature on social effects. Evidence of social effects as determinant of individual behavior has been found in studies of crime (Case and Katz, 1991, Glaeser, Sacerdote and Scheinkman, 1996, Ludwig, Duncan and Hirshfeld, 2001), welfare participation (Bertrand, Luttmer and Mullainathan, 2000), health (Katz, Kling and Liebman, 2001), educational outcomes (Sacerdote, 2001), social mobility (Borjas, 1992, 1994), local spillovers and unemployment (Topa, 2001), or shirking behavior (Ichino and Maggi, 2000). Among these, Ichino and Maggi (2000) is the work most closely related to ours. Using data from human resources of a large Italian bank, the authors examine workers' propensity to shirk and find that it depends on individual characteristics, groupinteraction effects, as well as sorting of workers across regions.

\footnotetext{
${ }^{3}$ A similar framework is also analyzed by Cadot (1987).
} 
These papers either proxy for social effects with average local characteristics or analyze the changes in outcomes for individuals who moved to different areas. In this context, the main methodological concern is the potential bias due to omitted variables. More precisely, the network proxy is likely to capture effects other than the network per se, because individuals with similar unobserved characteristics tend to belong to the same reference group, or because unobserved group's characteristics can systematically influence the dependent variable. One solution to the problem has been to analyze randomized experiments, such as the Moving to Opportunity experiment in Boston (Katz et al., 2001) and Baltimore (Ludwig et al., 2001), or the random assignment of roommates during the first year of college (Sacerdote, 2001). Alternatively, identifying the group of reference by more than one characteristic allows the use of fixed effect estimation at the local level and substantially reduces the potential for omitted variable bias. Bertrand et al. (2000) use this methodology to examine the role of social networks in welfare participation. They characterize the network of every individual by the language she speaks and the neighborhood she lives in: by characterizing the network with two indices (language and neighborhood), the authors are able to control for both neighborhood and language group unobservables. In our paper, we shall follow a similar approach (see section V.3 for details).

\section{II.3 Related Works Using WVS Data}

A growing economic literature has also used the World Value Survey to analyze the relationship between regional or individual values and economic phenomena. For instance, Knack and Keefer (1997) use the WVS to build various indexes of social capital, and find that social capital is positively correlated with aggregate economic activity. Swamy et al. (2001) show that women have on average a less tolerant attitude towards corruption. Guiso et al. (2002) study the relationship between the intensity and type of religious beliefs and socioeconomic attitudes, such as women's discrimination and trust in government. They find that, although religious people tend to trust others more and be more law abiding, people's attitudes strongly depend on the type of religion. Lastly, MacCulloch 
and Pezzini (2002) find that people's revolutionary attitudes depend both on the degree of freedom of the country they live in, and on their religious beliefs.

\section{Estimation Method}

Our main variable of interest is the individual attitude towards corruption. In the survey, respondents where asked if "Someone accepting a bribe in the course of their duties" is a statement they thought can always be justified, never be justified or something in between, using a coding system ranging from 1 (never justifiable) to 10 (always justifiable). Figure 1 presents the share of responses for each category. While 75.4 percent of individuals value the acceptance of bribes as an action that is never justifiable, 8.8 percent of the sample provided a rank of 5 or above thus showing a relatively high propensity to condone fraudulent behavior. We use the answer to this question as our measure of the attitude towards corruption. We then regress the individual attitudes towards corruption (BRIBE) on a set of personal characteristics and values, whose summary characteristics are presented in Table 1.

Specifically, we first investigate the determinants of individual attitudes towards corruption without including proxies for social effects, and estimate our specifications using ordinary least squares. Since more than $75 \%$ percent of individuals value the acceptance of bribes as an action that is never justifiable (which implies a substantial mass point at zero), we also performed tobit analyses. However, as results did not change significantly, we do not report them here. Estimation results for the basic specification are reported in Table 2. In column I we control for unobservables by including country fixed effects, while in column II we instead include regional dummies. We find that the estimates of personal characteristics are quite robust to the various regression specifications (see the detailed description below).

We then investigate the role of social effects. To do so, we first need to identify ex ante the reference group that may influence the individual's perception of corruption (Manski, 1993). In our case, it is likely that the individual's attitudes towards corruption depend to 
a great extent on their interactions with other individuals, as well as on their relation with the public administration. It seems therefore reasonable to choose as our reference group the different regions within each country, and proxy for the social effect with the average of BRIBE within the region where the individual lives (RBRIBE). In addition, the estimation of social effects raise two main methodological concern. The first is the potential bias of the coefficient estimate due to the presence of unobservables. For example, RBRIBE could capture the effect of national institutions that are likely to be correlated with the prevalence of corruption, such as the quality of the jurisdictional system. To correct for this possible bias, we add country fixed effects to the specification. Nevertheless, a similar problem could also arise at the regional level. Since a regional dummy would be perfectly collinear with RBRIBE, we address this issue in section V.2 by exploiting time differences in RBRIBE across two separated waves of the WVS - a first wave conducted in 1990-93 (Wave II) and a second wave conducted in 1995-97 (Wave III, our main dataset): time variation in regional averages of BRIBE allows us to include regional (time invariant) and national (time variant) dummies. Results of this estimation are reported in Table 3.

The second methodological concern is the identification of social effects. To clarify this issue, we follow Manski (1993) and write our regression as:

$$
y=\alpha+z^{\prime} \eta+\beta E(y \mid x)+E(z \mid x)^{\prime} \gamma+\varepsilon
$$

where, in our context, the constant $\alpha$ represents a national dummy capturing the average attitude towards corruption in the country as well as a host of unobservable country characteristics, $x$ represents the reference group to which the individual belongs (in our case, the region), $z$ represents personal characteristics, $E(y \mid x)$ is the average answer of the reference group (RBRIBE), and $E(z \mid x)$ represents average characteristics of the reference group (such as, for example, average education in the region). Manski (1993) defines $\beta E(y \mid x)+E(z \mid x)^{\prime} \gamma$ as the social effect. More precisely, in Manski's definition, $\beta E(y \mid x)$ captures the endogenous social effect purely due to peer effects, while 
$E(z \mid x)^{\prime} \eta$ represents the exogenous effect because it depends on the average distribution of fundamentals.

Manski (1993) shows that, unless additional assumptions are made, it is not possible to disentangle endogenous and exogenous social effects: in our case, this would mean that the estimated coefficient on RBRIBE might reflect both the effect of peer interaction as well as the influence of regional average characteristics on the individual attitudes towards corruption. However, as detailed in the introduction, it remains interesting to verify whether an overall social effect of either endogenous or exogenous nature affects individuals' attitudes towards corruption. To do so, note that, to test whether there are any social effects, we simply need to run the following regression:

$$
y=\alpha+\beta E(y \mid x)+z^{\prime} \eta+\varepsilon
$$

Under the null hypothesis that there are no social effects at all, estimations of the above regression would deliver insignificant estimates of $\beta$. Conversely, we can interpret a significant estimate of $\beta$ as evidence of social effects.

To implement the estimation we proceed as follows. First, we drop all countries that have only one region, so that only 35 countries are left in the sample (see Table 5). We then estimate the average $E\left(y_{-i} \mid x\right)$ for each region (RBRIBE- $)$, where the answer of individual $i$ is omitted from the regional average. We then regress the individual response $\left(\mathrm{BRIBE}_{i}\right)$ on a country dummy, on personal characteristics, and on the average answer $E\left(y_{-i} \mid x\right)$ in the region. Results are reported in Table 2, column III, and Table 3, column II.

Last, we choose not to use the weights provided in the WVS. As we shall see in the next section, several observations contain missing data. Hence, we perform our multivariate analysis without the use of the existing sampling weights. ${ }^{4}$ Consequently, we can not

\footnotetext{
${ }^{4}$ Nevertheless, we still impose uniform weights on individual observations such that all regions have the same relevance. This is because we analyze social effects at the regional level, so that the relevant observation unit is the region, not the individual. Moreover, as in this case we are not hampered by the missing
} 
claim our results to be representative at the national or regional level, but rather circumscribed to within sample inference.

\section{Data Description}

The data set we use for the analysis is the World Values Survey and European Values Survey, a cross-country program coordinated by the Institute for Social Research of the University of Michigan. The series is designed to enable a cross-national comparison on values and norms on a wide variety of topics. The novelty of the questionnaire is the coverage of a wide array of individual beliefs on politics, religion and economics. It also provides information on the demographic characteristics of the respondents and their selfreported economic profile. All surveys were carried out through individual interviews to adults aged 18 or older. Currently, three waves of the WVS are publicly available (1981$84,1990-93,1995-97)$. In most specifications we only use data from the 1995-97 wave of the WVS (Wave III). The third wave of the WVS comprises 55 surveys across 49 countries for a total of 78,574 individuals interviewed. ${ }^{5}$ The typical sampling design within each country is a multi-stage random selection of sampling points after stratification by region and degree of urbanization. ${ }^{6}$

As we are ultimately interested in measuring the impact of social effects at the regional level, we had to restrict the sample in a number of ways. First, we eliminated all country where the surveys did not contain the variables that are relevant for our analysis (for example, information on education was not available for Japan). Second, we excluded from the sample all surveys conducted on a regional rather than national scale (in Spain, for instance, in addition to the national survey, four additional regional surveys were conducted). Third, to identify social effects we used as a reference group the regional averages; hence, we eliminated all the surveys that did not contain any regional identification.

value problem, in order to guarantee that RBRIBE is representative at the regional level, we used the WVS weights in its computation.

${ }^{5}$ Few surveys were also administered at the sub-national level in Puerto Rico, Tabov District, Montenegro, the Andalusian, Basque, Gallician and Valencian regions of Spain, plus a pilot survey in Ghana. However, they were not included in our analysis (see below).

${ }^{6}$ For a detailed description of the datasets see Inglehart et al. (2000). 
Moreover, in order to guarantee some degree of representativity of the regional averages, we also excluded all regions with less than forty observations. Finally, a high number of individual observations were also dropped because of missing data on relevant covariates (see table 8). After these exclusions, our sample consists of 33,780 observations across 35 countries. In the resulting sample almost $40 \%$ of the subjects live in a town with more than 100,000 inhabitants, $55 \%$ of the subjects have secondary education, $29 \%$ define themselves as high income, and $24 \%$ are Christian orthodox.

To correct for omitted variable bias at the regional level, we also use data from the 199093 wave (Wave II). Although using the 1990-93 wave allows us to exploit time variations in the regional averages of individual attitudes towards corruption, there are disadvantages in pooling the two waves together. In particular, Wave II does not include data on education for most countries, contains a large number of missing observations and also covers a sample of countries and regions that overlaps only partially with that of Wave III. Consistent data for our specification were therefore available in both waves for only 36 regions in 5 countries.

\section{Empirical Results}

\section{V.1 Basic Specification}

Table 2 presents the regression estimates for all 35 countries. Note that by including national (or regional) dummies we implicitly run fixed effect regressions, such that every estimate has to be interpreted as the deviation with respect to the national (or regional) average. Relatively few variables are significantly correlated with BRIBE. However, these correlations are robust across the different regression specifications.

Consistent with the findings of previous studies (Dollar et al., 2001, and Swamy et al., 2001), women seem to be relatively more averse to corruption (lower BRIBE). We do not find a correlation between the degree of education and corruption, but richer individuals are more likely to accept some degree of corruption; in particular, this effect is consistently significant for high income people. People also appear to be more averse to corrup- 
tion as they age. Moreover, family values and reported church attendance are associated with higher aversion to corruption. Interestingly, different religious beliefs do not seem to have a significant impact on BRIBE (with the exception of individuals of Jewish religion who consistently report a higher aversion to corruption). Finally, we find that unemployed people display less aversion to corruption. Note that the magnitude of the estimated coefficients is not sensitive to whether the fixed effects are computed at the national or regional level (Table 2, columns I and II).

We then test for the presence of social effects (column III of Table 2). To do so, we simply regress BRIBE on the regional average RBRIBE without the observations of the single individuals, RBRIBE$_{-\mathrm{i}}$, while controlling for personal characteristics. As discussed in section III, we interpret RBRIBE as a proxy for both endogenous and exogenous social effects. We consistently find that $\hat{\beta}$ is significantly different from zero, indicating that social effects have overall a significant impact on the individual's perception of corruption. Moreover, the magnitude of the effect is sizeable - a one-standard deviation increase in RBRIBE is associated with an increase of $30 \%$ of a standard deviation in the individual attitude towards corruption. Note that the estimates of personal characteristics are quite robust across all regressions, even after including the social effect.

\section{2 High vs. Low and Middle Income Countries}

Empirical evidence tends to support the idea that, overall, corruption is associated with low economic performance (see, for instance, the reviews of Bardhan, 1997, and Tanzi, 1998). For example, the correlation between the index of absence of corruption developed by Transparency International (2002) and real GDP per capita is $0.88 .^{7}$ Similarly, across the 35 countries in our dataset higher corruption is associated with lower levels of development (correlation of -0.3). In particular, $73.3 \%$ of the respondents in developing countries consider accepting a bribe as never justifiable, while the percentage rises to $84.6 \%$ in more developed countries. In this context, it is interesting to investigate whether individuals residing in low/high income countries display structural differences with re-

\footnotetext{
${ }^{7}$ The corruption index of Transparency International varies from one to ten, where more corrupted countries obtain a lower score.
} 
gards to their attitudes towards corruption. ${ }^{8}$ To do so we run our basic regression as in Table 2 for individuals in low and high income countries separately, and then test for model equivalence. Interestingly, we obtain that individuals' behavior is independent from the level of development of the country of residence. ${ }^{9}$ In other words, despite the difference in average responses reported above, individual characteristics and social effects appear to affect the perception of corruption in the same fashion both in low and high income countries.

\section{V.3 Regional Unobservables}

We cannot rule out that, besides the social effect, RBRIBE also captures a regional fixed effect. To address this issue, we use data from two consecutive waves of the WVS so that we can exploit time variation in RBRIBE while including a regional dummy. More precisely, when exploiting time differences in RBRIBE for every region, we are able to add both regional and country-year dummies. Table 3 presents the results for the sample of regions that are both in Wave II and Wave III. In order to keep the sample size as large as possible, we have used only a subset of the original explanatory variables: in particular, we have dropped educational variables because Wave II did not contain information on the individual's educational level, and we have also eliminated religious beliefs as well as number of children because they significantly decreased the number of observations. However, in light of the robustness of the results of the previous regressions, we do not expect this to significantly alter the estimated coefficient on RBRIBE.

As for the effect of individual characteristics, the estimates tend to confirm our previous results. Women, older individuals, and individuals that have strong family and religious values tend to be more adverse to corruption. As for the social effect, we find RBRIBE to be still significant (at the 10\% level), but with a lower estimated magnitude of 0.36 (about half the size of the estimated effect in table 2, column III). A number or factors can explain the smaller magnitude. First, by adding regional and country-time dummies, we analyze whether a higher than average RBRIBE with respect to both the regional av-

\footnotetext{
${ }^{8}$ Low/high income countries are defined here as countries with GDP per capita below/above 9000 US \$ in 1995.

${ }^{9}$ The results of the Chow tests performed are $\mathrm{F}(24,33697)=1.48$ for regression (I), $\mathrm{F}(24,33454)=0.81$ for regression (II), and $\mathrm{F}(25,33695)=1.24$ for regression (III). Therefore, we can not reject the null hypothesis that the two models are equivalent.
} 
erage over the two years and the country average of that year has a positive influence on the individual perception of corruption. Moreover, this setup is quite restrictive, as it requires that the individual perceptions of corruption respond to changes in the social environment within the relatively short period of time that separates the two waves of interview (5 years).

\section{Conclusions}

Although issues of governance and corruption have been recently at the center of the academic and policymaking debates, the literature documenting the determinants of corruption at the microeconomic level is scant. This paper attempts to fill this gap in two distinct directions. First, using data from the World Value Survey, a large dataset containing, amongst others, information on personal attitudes towards corruption in more than 50 countries of the developed and developing world, we consistently find women, employed, less wealthy, and older individuals to be more averse to corruption. Second, we investigate the extent to which the social environment influences individual attitudes towards corruption. We find that, ceteris paribus, individuals tend to be more forgiving of corruption in regions where, on average, people are relatively less averse to it. Moreover, the social effect seems to be of sizeable magnitude. This suggests that the individual incentives to oppose corruption might be low, and that an effective fight against corruption may need to be a coordinated "big push" operating on several fronts at once. 


\section{References}

Ades, Alberto and Rafael Di Tella (1999). "Rents, Competition, and Corruption," American Economic Review, 89(4), 982-93.

Andvig, Jens C. and Karl O. Moene (1990). "How Corruption May Corrupt," Journal of Economic Behavior and Organization, 13, 63-76.

Banerjee, Abhijit (1997). “A Theory of Misgovernance," Quarterly Journal of Economics, 112(4), 1289-1332.

Bardhan, Pranab (1997). "Corruption and Development: A Review of Issues," Journal of Economic Literature, 35(3), 1320-46.

Baumol, William J (1990). "Entrepreneurship: Productive, Unproductive, and Destructive," Journal of Political Economy, 98, 893-921.

Beck, Paul J and Michael W Maher (1986). "A Comparison of Bribery and Bidding in Thin Markets," Economics Letters, 20(1), 1-5.

Becker, Gary and George J. Stigler (1974). "Law Enforcement, Malfeasance, and the Compensation of Enforcers," Journal of Legal Studies, III, 1-19

Bertrand, Marianne, Erzo F. P. Luttmer and Sendhil Mullainathan (2000). "Network Effects and Welfare Cultures," The Quarterly Journal of Economics, 115(3), 1019-55.

Borjas, Geroge J. (1992). "Ethnic Capital and Intergenerational Mobility," The Quarterly Journal of Economics, 107, 123-50. 
----- (1994). "Long-Run Convergence of Ethnic Skill Differentials: The Children and Grandchildren of the Great Migration," Industrial and Labor Relations Review, 47, 55373.

Braun, Miguel, and Rafael di Tella (2002). "Inflation and Corruption," Harvard Business School, mimeo.

Cadot, Oliver (1987). "Corruption as a Gamble," Journal of Public Economics, 33, 22344.

Case, Anne and Lawrence Katz (1991). "The Company You Keep: The Effects of Family and Neighborhood on Disadvantaged Youths," NBER Working Paper 3705.

Collier, Paul (1999). "How to Reduce Corruption,” Manuscript, The World Bank.

Dollar, David, Raymond Fisman and Roberta Gatti (2001). "Are Women Really the "Fairer" Sex? Corruption and Women in Government," Journal of Economic Behavior and Organization, 46(4), 423-29.

Fisman, Raymond and Roberta Gatti (2002). "Decentralization and Corruption: Evidence across Countries," Journal of Public Economics, 83(3), 325-45.

Glaeser, Edward L, Bruce Sacerdote and José A Scheinkman (1996). "Crime and Social Interactions," The Quarterly Journal of Economics, 111, 507-48.

Guiso, Luigi, Paola Sapienza and Luigi Zingales (2002). "People’s Opium? Religion and Economic Attitudes," mimeo.

Huntington, Samuel (1968). Political Order in Changing Societies, Yale University Press, New Haven. 
Ichino, Andrea, and Giovanni Maggi (2000). "Work Environment and Individual Background: Explaining Regional Shirking Differentials in a Large Italian Firm," The Quarterly Journal of Economics, 115(3), 1057-90.

Inglehart, Ronald et Al. (2000). "World Value Surveys and European Value Surveys, 1981-1984, 1990-1993, 1995-1997,” ICPSR 2790, University of Michigan.

Kaufman, Daniel, Aart Kraay, and Pablo Zoido-Lobaton (1999). "Governance Matters," World Bank Policy Research Working Paper, no. 2196.

Katz, Lawrence F, Jeffrey R Kling and Jeffrey B Liebman (2001). "Moving to Opportunity in Boston: Early Result of a Randomized Mobility Experiment," The Quarterly Journal of Economics, 116(2), 607-54.

Knack, Steven and Philip Keefer (1997). "Does Social Capital Have an Economic Payoff? A Cross-Country Investigation," The Quarterly Journal of Economics, 112(4), 125188.

Krueger, Anne (1974). "The Political Economy of the Rent-Seeking Society," The American Economic Review, 64, 291-303.

Leff, Nathaniel, "Economic Development through Bureaucratic Corruption," American Behavioral Scientist, 8-14.

Lien, Da Hsiang Donald (1986). "A Note on Competitive Bribery Games," Economics Letters, 22(4), 337-41.

Ludwig, Jens, Greg J Duncan and Paul Hirshfeld (2001). "Urban Poverty and Juvenile Crime: Evidence from a Randomized Housing-Mobility Experiment," The Quarterly Journal of Economics, 116, 655-79. 
MacCulloch, Robert and Silvia Pezzini (2002). "Pricing Freedom with Revolutionary Preferences of Christians and Muslims," mimeo, London School of Economics.

Manski, Charles F (1993). "Identification of Endogenous Social Effects: The Reflection Problem," Review of Economic Studies, 60, 531-42.

Mauro, Paolo (1995). "Corruption and Growth," The Quarterly Journal of Economics, 110(3), 681-712.

------ (1997). "Corruption and the Composition of Government Expenditure," Journal of Public Economics, 69, 263-79.

Murphy, Kevin M, Andrei Shleifer and Robert W Vishny (1989). "Industrialization and The Big Push," The Journal of Political Economy, 97(5), 1003-26.

----- (1991). "The Allocation of Talent: Implication for Growth," The Quarterly Journal of Economics, 106, 503-30.

Paternostro, Stefano (1997) “The Poverty Trap: The Dual Externality Model and Its Policy Implications," World Development, 25 (12), 2071-81.

Rose-Ackerman, Susan (1978). Corruption: A Study of Political Economy, New York, Academic Press.

Rosenstein-Rodan, Paul (1943). "Problems of Industrialization of Eastern and SouthEastern Europe," Economic Journal, 53, 202-11.

Sacerdote, Bruce (2001). "Peer Effects with Random Assignment: Results for Dartmouth Roommates," The Quarterly Journal of Economics, 116(2), 681-704. 
Shleifer Andrei and Vishny Robert (1993). "Corruption," Quarterly Journal of Economics, 108, 599-617.

Swamy, Anand, Stephen Knack, Young Lee and Omar Azfar (2001). "Gender and Corruption," Journal of Development Economics, 64, 25-55.

Tanzi, Vito (1998). "Corruption Around the World: Causes, Consequences, Scope, and Cures," IMF Staff Papers, 45, 559-94.

Tirole, Jean (1996). "A Theory of Collective Reputations (with Applications to the Persistence of Corruption and to Firm Quality)" The Review of Economic Studies, 63(1), 122.

Topa, Giorgio (2001). "Social Interactions, Local Spillovers and Unemployment," Review of Economic Studies, 68, 261-295.

Transparency International (2002). Global Corruption Report 2002, www.transparency.org.

Treisman, Daniel (2000). "The Causes of Corruption: A Cross-National Study," Journal of Public Economics, 76(3), 399-457. 
Figure 1 Distribution of Answers

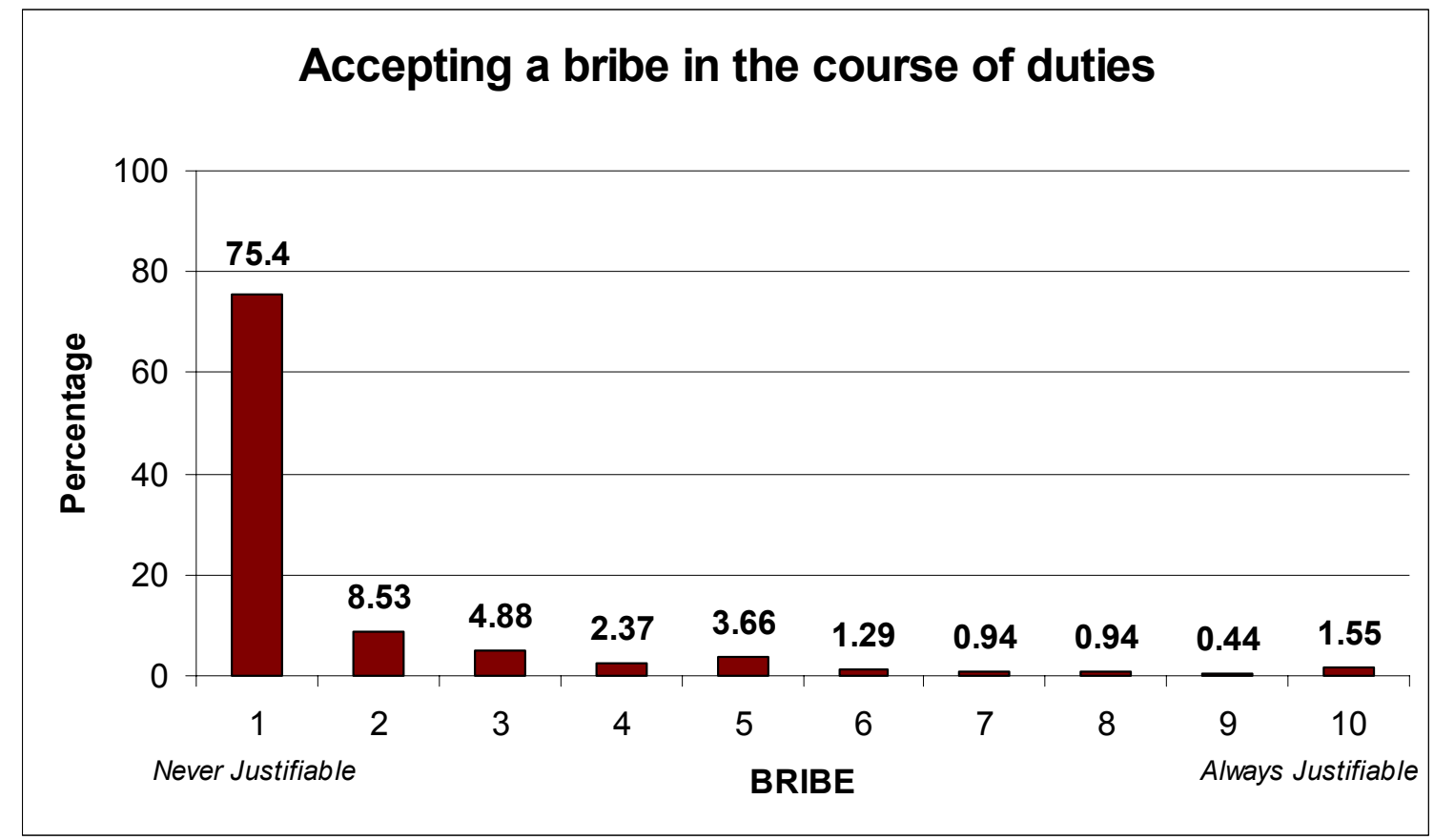


Table 1. Variables Definition and Summary Characteristics

\begin{tabular}{|c|c|c|c|c|}
\hline Variable & Description & $\begin{array}{c}\text { Mean } \\
1995\end{array}$ & $\begin{array}{c}\text { St. Dev. } \\
1995\end{array}$ & Dummy \\
\hline BRIBE & See paper & 1.76 & 1.78 & No \\
\hline RBRIBE & Regional average of $B R I B E$ & 1.79 & 0.65 & No \\
\hline SEX & Women $=1$ & 0.54 & 0.50 & Yes \\
\hline SECONDARY & Has secondary education & 0.55 & 0.50 & Yes \\
\hline TERTIARY & Has tertiary education & 0.20 & 0.40 & Yes \\
\hline MIDDLEINC & Defines himself as middle income & 0.35 & 0.48 & Yes \\
\hline HIGHINC & Defines himself as high income & 0.29 & 0.46 & Yes \\
\hline MIDDLETOWN & Lives in a town with $10.000-100.000$ inhabitants & 0.26 & 0.44 & Yes \\
\hline BIGTOWN & Lives in a town with more than 100.000 inhabitants & 0.39 & 0.49 & Yes \\
\hline YOUNG & 18-24 years old & 0.07 & 0.25 & Yes \\
\hline MIDOLD & 45-64 years old & 0.33 & 0.47 & Yes \\
\hline OLD & More than 64 years old & 0.12 & 0.33 & Yes \\
\hline FAMIMP & Gives importance to the family & 0.90 & 0.31 & Yes \\
\hline MARRIED & Married & 0.75 & 0.44 & Yes \\
\hline CHILDREN & Number of children & 2.26 & 1.42 & No \\
\hline $\mathrm{CHURCH}$ & Goes to church at least once a week & 0.20 & 0.40 & Yes \\
\hline CATHOLIC & Catholic & 0.23 & 0.42 & Yes \\
\hline PROTESTANT & Protestant & 0.09 & 0.28 & Yes \\
\hline ORTHODOX & Orthodox & 0.24 & 0.43 & Yes \\
\hline MUSLIM & Muslim & 0.06 & 0.24 & Yes \\
\hline JEW & Jew & 0.02 & 0.13 & Yes \\
\hline OTHERREL & Other religion & 0.16 & 0.37 & Yes \\
\hline RIGHT & Defines himself politically from the right & 0.16 & 0.36 & Yes \\
\hline CENTER & Defines himself politically from the center & 0.46 & 0.50 & Yes \\
\hline FULLTIME & Works fulltime & 0.37 & 0.48 & Yes \\
\hline UNEMP & Unemployed & 0.07 & 0.26 & Yes \\
\hline $\mathrm{RCHURCH}$ & Regional average of $\mathrm{CHURCH}$ & 0.19 & 0.21 & No \\
\hline RELIND & Regional religious fractionalization & 0.42 & 0.21 & No \\
\hline NATION & Nation & & & Yes \\
\hline
\end{tabular}


Table 2. Basic Specifications

\begin{tabular}{|c|c|c|c|c|c|c|}
\hline Dep. Var.: BRIBE & (I) & & (II) & & (III) & \\
\hline \multirow[t]{2}{*}{ RBRIBE } & & & & & 0.855 & $* * *$ \\
\hline & & & & & 20.59 & \\
\hline \multirow[t]{2}{*}{ SEX } & -0.071 & $* *$ & -0.086 & $* * *$ & -0.089 & $* * *$ \\
\hline & -2.11 & & -2.85 & & -3.03 & \\
\hline \multirow[t]{2}{*}{ SECONDARY } & 0.059 & * & 0.046 & & 0.046 & \\
\hline & 1.77 & & 1.47 & & 1.50 & \\
\hline \multirow[t]{2}{*}{ TERTIARY } & -0.036 & & -0.027 & & -0.024 & \\
\hline & -0.59 & & -0.52 & & -0.46 & \\
\hline \multirow[t]{2}{*}{ MIDDLEINC } & 0.086 & ** & 0.053 & & 0.067 & \\
\hline & 2.05 & & 1.28 & & 1.56 & \\
\hline \multirow[t]{2}{*}{ HIGHINC } & 0.174 & *** & 0.127 & *** & 0.147 & *** \\
\hline & 3.03 & & 2.68 & & 2.90 & \\
\hline \multirow[t]{2}{*}{ MIDDLETOWN } & 0.046 & & 0.045 & & 0.044 & \\
\hline & 0.89 & & 0.97 & & 1.00 & \\
\hline \multirow[t]{2}{*}{ BIGTOWN } & 0.062 & & 0.031 & & 0.007 & \\
\hline & 1.13 & & 0.54 & & 0.14 & \\
\hline \multirow[t]{2}{*}{ YOUNG } & 0.259 & *** & 0.261 & *** & 0.265 & *** \\
\hline & 2.80 & & 2.76 & & 2.77 & \\
\hline \multirow[t]{2}{*}{ MIDOLD } & -0.164 & *** & -0.194 & *** & -0.190 & *** \\
\hline & -5.30 & & -6.00 & & -6.20 & \\
\hline \multirow[t]{2}{*}{ OLD } & -0.221 & *** & -0.271 & *** & -0.264 & $* * *$ \\
\hline & -4.13 & & -5.10 & & -5.22 & \\
\hline \multirow[t]{2}{*}{ FAMIMP } & -0.287 & *** & -0.299 & $* * *$ & -0.302 & $* * *$ \\
\hline & -5.12 & & -5.36 & & -5.55 & \\
\hline \multirow[t]{2}{*}{ MARRIED } & -0.076 & * & -0.072 & * & -0.074 & * \\
\hline & -1.78 & & -1.90 & & -1.90 & \\
\hline \multirow[t]{2}{*}{ CHILDREN } & -0.021 & & -0.010 & & -0.009 & \\
\hline & -1.50 & & -0.97 & & -0.77 & \\
\hline \multirow[t]{2}{*}{$\mathrm{CHURCH}$} & -0.093 & $* *$ & -0.071 & $* *$ & -0.073 & ** \\
\hline & -2.42 & & -2.16 & & -2.19 & \\
\hline \multirow[t]{2}{*}{ CATHOLIC } & 0.087 & & 0.138 & * & 0.121 & * \\
\hline & 1.30 & & 1.72 & & 1.76 & \\
\hline \multirow[t]{2}{*}{ PROTESTANT } & 0.028 & & 0.029 & & 0.036 & \\
\hline & 0.60 & & 0.58 & & 0.77 & \\
\hline ORTHODOX & -0.077 & & -0.087 & & -0.078 & \\
\hline & -1.04 & & -1.29 & & -1.29 & \\
\hline MUSLIM & -0.117 & & -0.207 & ** & -0.148 & \\
\hline & -1.13 & & -2.07 & & -1.53 & \\
\hline JEW & -0.153 & ** & -0.135 & * & -0.146 & ** \\
\hline & -1.96 & & -1.83 & & -2.11 & \\
\hline OTHERREL & 0.087 & * & 0.056 & & 0.072 & \\
\hline & 1.69 & & 0.92 & & 1.25 & \\
\hline RIGHT & 0.085 & & 0.096 & * & 0.076 & \\
\hline & 1.41 & & 1.93 & & 1.56 & \\
\hline CENTER & 0.039 & & 0.023 & & 0.016 & \\
\hline & 0.96 & & 0.57 & & 0.42 & \\
\hline FULL & -0.011 & & -0.013 & & -0.019 & \\
\hline & -0.34 & & -0.45 & & -0.71 & \\
\hline UNEMP & 0.155 & $* *$ & 0.120 & $* *$ & 0.122 & $* *$ \\
\hline & 2.21 & & 2.27 & & 2.28 & \\
\hline CONSTANT & 1.941 & *** & 1.750 & *** & 0.473 & $* * *$ \\
\hline & 18.19 & & 16.14 & & 3.38 & \\
\hline Obs. & 33780 & & 33780 & & 33780 & \\
\hline Nations & 35 & & 35 & & 35 & \\
\hline Regions & 278 & & 278 & & 278 & \\
\hline Dummy & National & & Regional & & National & \\
\hline
\end{tabular}

Reference categories - for education: primary schooling; for income: low income; for age: 25-44; geographic: smalltown: $<10,000$ inhabitants; religion: no religion; political: left wing; employment: self employed and working part-time. *: significant at the $10 \%$ level; **: significant at the $5 \%$ level; ***: significant at the $1 \%$ level. 
Table 3. Controlling for unobservables: regressions on data from Wave II and Wave III with regional and country-year fixed effects

\begin{tabular}{|c|c|c|c|c|}
\hline Dep. Var.: BRIBE & (I) & & (II) & \\
\hline RBRIBE & & & $\begin{array}{c}0.366 \\
1.7\end{array}$ & * \\
\hline SEX & $\begin{array}{c}-0.104 \\
-2.54\end{array}$ & ** & $\begin{array}{l}-0.103 \\
-2.53\end{array}$ & ** \\
\hline MIDDLEINC & $\begin{array}{l}-0.019 \\
-0.34\end{array}$ & & $\begin{array}{l}-0.020 \\
-0.35\end{array}$ & \\
\hline HIGHINC & $\begin{array}{l}0.010 \\
0.17\end{array}$ & & $\begin{array}{l}0.007 \\
0.12\end{array}$ & \\
\hline MIDDLETOWN & $\begin{array}{l}-0.018 \\
-0.44\end{array}$ & & $\begin{array}{l}-0.016 \\
-0.38\end{array}$ & \\
\hline BIGTOWN & $\begin{array}{c}0.091 \\
1.27\end{array}$ & & $\begin{array}{c}0.093 \\
1.34\end{array}$ & \\
\hline YOUNG & $\begin{array}{l}0.265 \\
4.75\end{array}$ & $* * *$ & $\begin{array}{l}0.265 \\
4.74\end{array}$ & $* * *$ \\
\hline MIDOLD & $\begin{array}{l}-0.171 \\
-4.11\end{array}$ & *** & $\begin{array}{l}-0.171 \\
-4.06\end{array}$ & $* * *$ \\
\hline OLD & $\begin{array}{l}-0.214 \\
-3.01\end{array}$ & *** & $\begin{array}{l}-0.217 \\
-3.03\end{array}$ & $* * *$ \\
\hline FAMIMP & $\begin{array}{l}-0.280 \\
-4.47\end{array}$ & $* * *$ & $\begin{array}{l}-0.276 \\
-4.45\end{array}$ & $* * *$ \\
\hline MARRIED & $\begin{array}{l}-0.109 \\
-3.27\end{array}$ & $* * *$ & $\begin{array}{l}-0.108 \\
-3.34\end{array}$ & $* * *$ \\
\hline $\mathrm{CHURCH}$ & $\begin{array}{c}-0.073 \\
-2.6\end{array}$ & $* * *$ & $\begin{array}{l}-0.073 \\
-2.57\end{array}$ & ** \\
\hline RIGHT & $\begin{array}{l}0.019 \\
0.29\end{array}$ & & $\begin{array}{l}0.022 \\
0.34\end{array}$ & \\
\hline CENTER & $\begin{array}{l}0.036 \\
0.69\end{array}$ & & $\begin{array}{l}0.037 \\
0.71\end{array}$ & \\
\hline FULL & $\begin{array}{l}-0.084 \\
-2.79\end{array}$ & $* * *$ & $\begin{array}{l}-0.082 \\
-2.74\end{array}$ & $* * *$ \\
\hline UNEMP & $\begin{array}{l}-0.007 \\
-0.09\end{array}$ & & $\begin{array}{l}-0.006 \\
-0.08\end{array}$ & \\
\hline CONSTANT & $\begin{array}{c}1.87 \\
16.43 \\
\end{array}$ & $* * *$ & $\begin{array}{l}1.32 \\
4.08 \\
\end{array}$ & $* * *$ \\
\hline Obs. & 14476 & & 14476 & \\
\hline Nations & 5 & & 5 & \\
\hline $\begin{array}{l}\text { Regions } \\
\text { Dummy }\end{array}$ & $\begin{array}{c}36 \\
\text { Regional }\end{array}$ & & $\begin{array}{c}36 \\
\text { Regional }\end{array}$ & \\
\hline
\end{tabular}

Reference categories - for income: low income; for age: 25-44; geographic: smalltown: $<10,000$ inhabitants; political: left wing; employment: self employed and working part-time. *: significant at the $10 \%$ level; **: significant at the $5 \%$ level; ***: significant at the $1 \%$ level. 
Table 4. Country List and BRIBE averages

\begin{tabular}{|c|c|c|c|c|c|c|}
\hline Country & Observations 1995 & Observations 1990 & $\begin{array}{c}\text { Average } B R I B E \\
1995 \\
\end{array}$ & $\begin{array}{c}\text { Average } B R I B E \\
1990 \\
\end{array}$ & $\begin{array}{l}\text { Only } 1 \\
\text { region } \\
\end{array}$ & $\begin{array}{c}\text { High } \\
\text { Income }\end{array}$ \\
\hline Armenia & 1290 & & 2.10 & & & \\
\hline Australia & 1299 & & 1.28 & & & Yes \\
\hline Azerbaijan & 1220 & & 2.67 & & & \\
\hline Bangladesh & 1388 & & 1.03 & & & \\
\hline Belarus & 1648 & & 1.98 & & & \\
\hline Bosnia & 1165 & & 1.57 & & & \\
\hline Brazil & 770 & 1662 & 4.00 & 1.39 & & \\
\hline Bulgaria & 984 & & 1.89 & & & \\
\hline Chile & 719 & & 1.68 & & & \\
\hline China & 1207 & & 1.20 & & & \\
\hline Croatia & 823 & & 2.04 & & & \\
\hline Dominican Republic & 181 & & 1.82 & & & \\
\hline East Germany & 775 & & 1.99 & & & Yes \\
\hline Estonia & 609 & & 1.51 & & & \\
\hline Finland & 592 & & 1.42 & & & Yes \\
\hline Georgia & 2452 & & 1.88 & & & \\
\hline Latvia & 378 & & 1.98 & & & \\
\hline Lithuania & 766 & & 1.89 & & & \\
\hline Macedonia & 960 & & 1.40 & & & \\
\hline Mexico & 957 & 1486 & 2.33 & 2.75 & & \\
\hline Moldova & 559 & & 2.25 & & & \\
\hline Montenegro & 168 & & 1.54 & & & \\
\hline Nigeria & 1166 & & 1.89 & & & \\
\hline Peru & 770 & & 1.62 & & & \\
\hline Russia & 1678 & & 1.50 & & & \\
\hline Serbia & 922 & & 1.38 & & & \\
\hline Slovenia & 642 & & 1.84 & & & Yes \\
\hline Spain & 663 & 3556 & 1.36 & 1.49 & & Yes \\
\hline Switzerland & 713 & & 1.51 & & & Yes \\
\hline Taiwan & 909 & & 1.68 & & & \\
\hline U.S.A. & 1092 & 1712 & 1.21 & 1.48 & & Yes \\
\hline Ukraine & 2244 & & 1.87 & & & \\
\hline Uruguay & 655 & & 1.27 & & & \\
\hline Venezuela & 858 & & 2.34 & & & \\
\hline West Germany & 558 & 1937 & 1.82 & 1.91 & & Yes \\
\hline
\end{tabular}

